\title{
Effects of a Subacute Ruminal Acidosis Model on the Diet Selection of Dairy Cows
}

\author{
J. E. Keunen, ${ }^{\star}$ J. C. Plaizier,†L. Kyriazakis,‡ T. F. Duffield,§ T. M. Widowski, ${ }^{\star}$ \\ M. I. Lindinger, $\|$ and B. W. McBride* \\ *Department of Animal and Poultry Science, University of Guelph, Guelph, Ontario, Canada NIG2W1, \\ †Department of Animal Science, University of Manitoba, Winnipeg, Manitoba, Canada R3T 2N2, \\ $\ddagger$ Animal Nutrition and Health Department, Animal Biology Division, Scottish Agricultural College, \\ King's Buildings, West Mains Road, Edinburgh, UK EH9 3JG, \\ $\S$ Department of Population Medicine, University of Guelph, Guelph, Ontario, Canada N1G 2W1, \\ \$Department of Human Biology and Nutritional Sciences, University of Guelph, Guelph, Ontario, Canada N1G 2W1
}

\section{ABSTRACT}

Two experiments were conducted to study the effects of a subacute ruminal acidosis (SARA) model on diet choice in dairy cows. In the first experiment, $25 \%$ of the ad libitum dry matter intake (DMI) of the total mixed ration (TMR) was replaced with wheat-barley pellets (WBP, $50 \%$ ground wheat, $50 \%$ ground barley). Rumen $\mathrm{pH}$ was measured continuously via in-dwelling probes in 4 mid to late lactation cows. This diet change reduced rumen $\mathrm{pH}$ by $0.14 \pm 0.02 \mathrm{pH}$ units (mean $\pm \mathrm{SE}$ ) and increased time below $\mathrm{pH} 6.0$, from $319 \pm 36 \mathrm{~min}^{-1}$ to $641 \pm 36 \mathrm{~min}^{-1}$. Hence, the nutritional model successfully induced SARA. The second experiment determined if inducing SARA increases the feed preference for long alfalfa hay compared with alfalfa pellets. The 2 wk of inducing SARA were separated by 1 control wk. Four cows on either SARA and control diets were given a choice of 2 feeds, 2 times per d, for $30 \mathrm{~min}$. The preference ratios $(\mathrm{PR}=$ Amount of Hay consumed/Amount of Hay + Pellets consumed) for alfalfa hay during two SARA weeks was greater $(0.85 \pm 0.03)$ compared with the control week $(0.60 \pm 0.03)$. In SARA weeks, average rumen $\mathrm{pH}$ was $0.23 \pm 0.03$ units lower, and time below pH 6.0 and 5.6 was higher compared to control. These results suggest that when given a choice of feeds, dairy cows alter their diet selection to attempt to attenuate SARA.

(Key words: Subacute ruminal acidosis; dairy cow; diet selection)

Abbreviation key: $\mathbf{P R}=$ preference ratio, $\mathbf{S A R A}=$ subacute ruminal acidosis, $\mathbf{W B P}=$ wheat barley pellets

Received November 19, 2001.

Accepted April 22, 2002.

Corresponding author: B.W. McBride; e-mail bmcbride@ uoguelph.ca

\section{INTRODUCTION}

The transition from the pregnant non-lactating state to the non-pregnant lactating state is the period during which the majority of metabolic diseases occur (Duffield et al., 1999). During this period, which ranges from 3 wk before until $3 \mathrm{wk}$ after calving, the cow is switched from a high-fiber, low concentrate diet to a diet that is higher in concentrate feeds and lower in fiber. Cows that have not been adapted to these high grain diets are particularly susceptible to ruminal acidosis (Owens and Goetsch, 1988). Subacute ruminal acidosis (SARA) is characterized by repeated bouts of depressed rumen $\mathrm{pH}$ between 5.2 and 5.6 (Cooper and Klopfenstein, 1996). The disorder often results from a large intake of rapidly fermentable carbohydrates that leads to the accumulation of organic acids in the rumen (Britton and Stock, 1987; Oetzel et al., 1999). Oetzel et al. (1999) have shown that $20 \%$ of commercial dairy farm cows in early- to mid-lactation have rumen $\mathrm{pH}$ of $<5.5$, indicative of SARA. SARA has been shown to lead to, or is associated with, reduced feed intake, loose feces/diarrhea, decreased milk production, liver abscesses, rumenitis, and lameness/laminitis (Underwood, 1992; Nocek, 1997). Costs of SARA have been estimated at $\$ 1.12$ per cow per day (Stone, 1999). Hence, SARA is a major concern within the dairy industry.

Scientists have attempted to mimic SARA to study possible solutions to this costly disease. Researchers have been able to induce acute ruminal acidosis by withholding feed for 12 to $24 \mathrm{~h}$ and then allowing cows access to the withheld diet (Owens et al., 1988). Although this method proves effective in reducing ruminal $\mathrm{pH}$, it is not representative of the events leading to SARA. Kyriazakis et al. (1999) suggested that an animal will alter its diet selection if a physiological change such as altered rumen state is of sufficiently large magnitude to be detected by the animal, rather than a shortterm systemic fluctuation that occurs in its internal state during a day. Thus, one of our objectives in this 
study was to create a nutritional model that will lower rumen $\mathrm{pH}$ in midlactation dairy cows to levels often observed in transition dairy cows. It was our goal upon achievement of this SARA model to provide dairy cows with a dietary selection that would allow them to attenuate SARA. It was therefore hypothesized that the SARA induction will be of sufficient physiological magnitude to alter diet selection. Several researchers have observed that sheep make appropriate dietary choices to help attenuate ruminal acidosis (Cooper et al., 1995; Cooper at al., 1996; Phy and Provenza, 1998a; Phy and Provenza, 1998b). Of these, Cooper et al. (1995) demonstrated that sheep appear to take rumen state into account when making diet selections. We provided a dietary choice by providing feeds of similar chemical composition but differing in particle size, as large particle size feed (alfalfa hay) is better able to reduce SARA than small particle feed (alfalfa pellets). Although work has been done on voluntary intake of feeds differing in particle size (Castle et al, 1979; Woodford and Murphy, 1988) using dairy cows, to our knowledge, no work has been done on feed particle size and diet selection in an altered rumen state in dairy cows. It was hypothesized that the cows would increase their dietary preference for longer particle size feeds during bouts of SARA.

\section{MATERIALS AND METHODS}

\section{Animals for Experiment $1 \& 2$}

Four rumen-fistulated Holstein dairy cows of second and third parity were housed in tie stalls in the physiology wing at the Elora Dairy Research Centre (EDRC) and were used in two experiments. Cows had unlimited access to fresh water and were milked twice daily in their stalls. All cows were in the mid to late stage of lactation during the experiments. All experimental procedures were done with the approval of the University of Guelph Animal Care Committee in accordance with the Canadian Council on Animal Care. Cows had been fitted with rumen fistulas according to Duffield (1999). Average weight during both experiments was $674 \pm 107$ $\mathrm{kg}$ (mean $\pm \mathrm{SD})$. DIM were $186 \pm 18 \mathrm{~d}$ at the beginning of the experiment 1 , and $233 \pm 18 \mathrm{DIM}$ at the start of experiment 2 .

\section{Experimental Procedures - Experiment $1 \& 2$}

Experiment 1 was a 4 -wk experiment. During wk 1 and 3 , a total mixed ration (TMR, Table 1 ) was provided ad libitum. SARA was induced during d 1 to 5 (Mon through Fri) of wk 2 and 4 . We replaced $25 \%$ of the TMR DMI measured in the previous period with an equal amount of DM from pellets containing 50\% ground wheat and 50\% ground barley (WBP), and re- stricted access to TMR (Figure 1). Daily amounts of WBP ranged from 6.1 to $7.1 \mathrm{~kg}$.

Experiment 2 was also a 4 -wk experiment conducted $21 \mathrm{~d}$ after the end of experiment 1 . Wk 1 was used to introduce the two test feeds (long stem alfalfa hay and alfalfa pellets) (Table 1) to the animals. In wk 2 and 4, cows were again supplemented with grain (50\% ground wheat, 50\% ground barley) pellets to induce SARA, while during wk 3 (control) cows were given ad libitum access to their TMR.

\section{Feeding Protocol - Experiment 1 - Development of SARA Model}

Prior to the start of the experiment, daily ad libitum intake of feed was recorded to determine dry matter intakes of the feed for wk 1 of the experiment. For each week of supplementation that the cows experienced, the previous week's ad libitum intakes were used to determine level of feeding and supplementation. During wk 1 and 3 of this experiment, cows were fed a TMR (Table 1) for lactating cows that did not contain added sodium bicarbonate. This ration was fed twice daily at $7 \mathrm{am}$ and $1 \mathrm{pm}$. During wk 2 and 4 (SARA) of the experiment, $25 \%$ of the ad libitum intake of TMR ration on a dry matter basis was replaced with WBP. At 7 am, $2 \mathrm{~kg}$ of the TMR was given to the cows. At $9 \mathrm{am}$, twothirds of the WBP were given to the animals. Between 11 and 11:30 am, the cows were again given access to their TMR, which was followed by the remainder of the WBP at $1 \mathrm{pm}$. From 3 to $3: 30 \mathrm{pm}$, the cows were again given access to their TMR, and at $5 \mathrm{pm}$ the cows were given access to the TMR for the remainder of the day (Figure1). If animals failed to consume all grain pellets within $1 \mathrm{hr}$ post feeding, the remaining pellets were introduced into the rumen through the fistula.

\section{Feeding Protocol - Experiment 2 - Diet Choice}

During wk 1 of the trial, the cows were allowed to experience both test feeds for 7 days so that no novel preference to or avoidance of the feeds would occur. This was accomplished by providing the cows with free access to the feeds in the trays for $30 \mathrm{~min} \cdot \mathrm{d}^{-1}$, during one of the two designated choice periods (11 to 11:30 am or 3 to $3: 30 \mathrm{pm}$ ). The feeds were presented to the cows in the feed trays that were used in the diet choice experiment. In wk 2 and 4, the cows were subjected to the WBP supplementation and TMR restriction regimen, while in wk 3 the cows had ad libitum access to their TMR. The supplementation of WBP and the preference tests took place on 1 to 5 of all 3 experimental wk. The feeding protocol for this trial was the same as in experiment 1 (Figure 1), except for one change. 
Table 1. Ingredient composition and dietary anaysis for experimental diets.

\begin{tabular}{|c|c|c|c|c|}
\hline Item & TMR & WBP & $\begin{array}{l}\text { Alfalfa } \\
\text { pellets }\end{array}$ & Alfalfa hay \\
\hline \multicolumn{5}{|l|}{ Ingredient } \\
\hline Corn silage & 41 & & & \\
\hline Alfalfa silage & 21 & & & \\
\hline High moisture corn & 17 & & & \\
\hline Mixed hay & 6 & & & \\
\hline Supplement ${ }^{1}$ & 16 & & & \\
\hline Ground wheat & & 50 & & \\
\hline Ground barley & & 50 & & \\
\hline Long stem alfalfa hay & & & & 100 \\
\hline Ground alfalfa hay & & & 100 & \\
\hline \multicolumn{5}{|l|}{ Chemical analysis } \\
\hline Dry Matter(\%) & 48.0 & 87.3 & 92.1 & 90.0 \\
\hline $\mathrm{CP}(\% \mathrm{DM})$ & 18.0 & 12.5 & 18.1 & 20.0 \\
\hline $\mathrm{NDF}(\% \mathrm{DM})$ & 36.5 & 16.4 & 45.7 & 42.5 \\
\hline $\mathrm{ADF}(\% \mathrm{DM})$ & 25.9 & 4.2 & 33.2 & 34.3 \\
\hline $\mathrm{Ca}(\% \mathrm{DM})$ & 0.93 & 0.04 & 1.87 & 1.35 \\
\hline $\mathrm{P}(\% \mathrm{DM})$ & 0.47 & 0.40 & 0.23 & 0.31 \\
\hline
\end{tabular}

${ }^{1}$ Contained (as fed basis) $3.92 \%$ blood meal, $8.59 \%$ corn gluten meal, $20.61 \%$ soy bean meal, $2.65 \%$ dicalcium phosphate, $2.94 \%$ calcium carbonate, $1.03 \%$ magnesium oxide, $1.77 \%$ salt, $0.88 \%$ Dynamate $(22 \% \mathrm{~S}, 18 \%$ IC, $11 \% \mathrm{Mg}$, IMC Feed Ingredients, Lake Forest, IL), 0.44\% Dairyman's EdgeTM (yeast, LBJ Pakke Inc., Waddington, NY), 0.26\% FFM Micro premix (Dicalcium phosphate, Calcium Carbonate, Magnesium Oxide, trace minerals, Vit A, Vit D, Vit E, Floradale Feedmill, Floradale, ON), 5.89\% wheat shorts, $2.21 \%$ fish meal, $22.08 \%$ soybean hulls, 3.68\% molasses, $0.22 \%$ Alimet DL-Methionine Hydroxy Analogue, Novus, St. Louis MO) $7.36 \%$ wheat grain, $11.04 \%$ roasted soybean, and $1.47 \%$ potassioum chloride.

Instead of TMR from 11 to 11:30 am and 3 to $3: 30 \mathrm{pm}$, the cows were given a preference test of two test feeds, alfalfa hay and alfalfa pellets, that were similar in chemical composition (Table 1) but differed in physical form (particle size). The two test feeds were each offered in $3-\mathrm{kg}$ amounts in identical feed trays placed in front of the cows. The side of the feed manger that the trays were on was randomized beforehand and remained the same for wk 2 and 3, and was switched for wk 4 to ensure that side did not affect diet selection. The preference ratio $(\mathrm{PR})$ during the three experimental weeks for the alfalfa hay vs the alfalfa pellets was calculated as the total amount of alfalfa hay consumed over the total amount of alfalfa hay and alfalfa pellets consumed during each 30 min period.

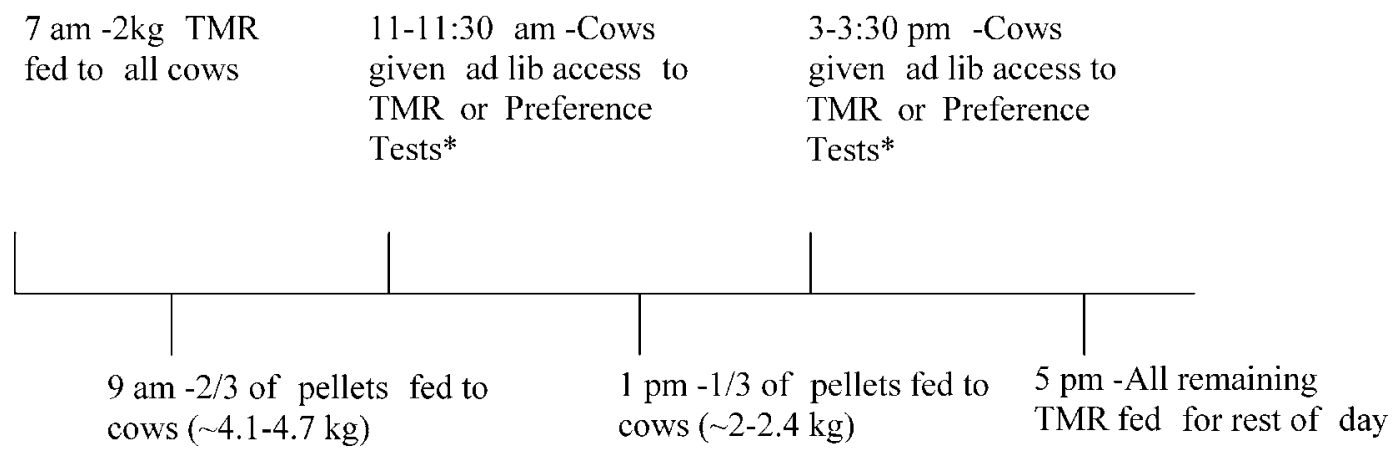

3-3:30 pm -Cows

or Preference

ThR fed for rest of day

\section{DMI and Feed Analysis}

The amounts of TMR and WBP consumed by each cow were recorded daily. Samples of the TMR and a representative sample of orts were taken daily and frozen. Orts were weighed every morning prior to that day's feeding. TMR samples were pooled by week, and orts samples were pooled by weight for each cow and week. DM of feeds and orts were determined by drying in an oven at $60^{\circ} \mathrm{C}$ for $48 \mathrm{~h}$ (AOAC, 1990). Dried samples of TMR, WBP, alfalfa hay and alfalfa pellets were analyzed for CP with the macro-Kjeldahl procedure (AOAC, 1990), ADF (AOAC, 1990; Undersander et al., 1993), and NDF (Goering and van Soest, 1970). Ca and P were determined by inductively coupled plasma spectroscopy

Figure 1. Daily Feeding Schedule for Model Development and Diet Selection Experiment. 
(AOAC, 1990) with a Perkin Elmer Optima 3000 spectrophotometer.

\section{Continuous Rumen pH Monitoring}

Continuous measurement of rumen $\mathrm{pH}$ was conducted using an adaptation of the technique used by Dado and Allen (1993) as described by Plaizier et al. (1999). A Sensorex Combi pH Electrode 450 CD (Sensorex, Stanton, CA) was placed through the fistula into the anterior region of the ventral sac of the rumen. Each $\mathrm{pH}$ electrode was protected by a wire shield and attached to a $0.5-\mathrm{kg}$ weight to maintain its location in the rumen. Tygon tubing protected each $\mathrm{pH}$ electrode and cable from the rumen environment by preventing liquid from damaging the cables. The $\mathrm{pH}$ electrode was connected to a Jenco Digital $\mathrm{pH}$ Transmitter Model 691N (Jenco Inc., La Jolla, CA) The $\mathrm{pH}$ transmitter output was captured by a Universal Analog Input Multiplexer EXP-16 (Omega Engineering Inc., Stamford, CT) and a DAS-8 analogue input board (Omega Engineering Inc., Stamford, CT) installed on a Pentium personal computer. The software use in the data capturing was Labtech Notebook Version 10 (Laboratory Technologies Corporation, Wilmington, MA). A pH reading was taken every second, with averages of every 60 -s period stored in the computer. The position of the $\mathrm{pH}$ electrode was checked at least once per day by palpation through the rumen fistula. Electrodes and $\mathrm{pH}$ transmitters were calibrated at least once per week using $\mathrm{pH} 4$ and 7 buffer solutions (Fisher Scientific, Fairlawn, NJ). Rumen fluid was sampled once per day for $\mathrm{pH}$ measurement and compared with continuous $\mathrm{pH}$ recordings to ensure the $\mathrm{pH}$ probes were recording accurate readings.

\section{Analysis of pH Data}

In developing a nutritional model to induce SARA and maintain low rumen $\mathrm{pH}$ for extended periods of time, certain variables or markers were set in order to ensure that SARA was induced. Several studies have suggested rumen $\mathrm{pH}$ values indicative of the onset of SARA. Cooper and Klopfenstein (1996) stated that SARA occurs at rumen $\mathrm{pH}$ between 5.2 and 5.6. Garrett et al. (1999) and Oetzel et al. (1999) stated that SARA occurs at rumen $\mathrm{pH}$ below 5.5. Plaizier et al. (1999) used $\mathrm{pH} 5.6$ as the threshold point for SARA. Time below rumen $\mathrm{pH} 6.0$ was also monitored in the present study, since microbial fiber digestion and nutrient digestibilities are reduced below this rumen $\mathrm{pH}$ (Calsamiglia et al., 1999; Owens and Goetsch, 1988). Data from our lab has shown that in vivo NDF degradability of mixed hay was reduced from $39.5 \%$ to $30.9 \%$ during SARA (Plaizier et al., 2001). Using these two criteria of rumen $\mathrm{pH}$ (time and area below $\mathrm{pH} 6.0$ and $\mathrm{pH}$ 5.6), we characterized rumen fluid variables to quantify SARA. For each cow and each 24-h period, averages of daily $\mathrm{pH}$, durations below $\mathrm{pH} 6.0$ and 5.6, and areas (time $\times \mathrm{pH}$ ) of $\mathrm{pH}$ below 6.0 and $\mathrm{pH} 5.6$ were calculated. These analyses identified the maximum and minimum rumen $\mathrm{pH}$ achieved by each cow for that day, and also provided the standard deviation. Areas below $\mathrm{pH} 6.0$ and 5.6 were calculated as the product of time ( $\mathrm{min}$ ) and deviation $(0.1 \mathrm{pH}$ unit) from the designated $\mathrm{pH}$ value [i.e. $5 \mathrm{~min}$ at $\mathrm{pH} 5.8$ (0.2 units below 6.0$)$ would be calculated as $5 \min \times 0.2=1$ unit of area $(\min \times \mathrm{pH})$ ].

\section{Statistical Analysis}

Data were compared using analysis of variance (ANOVA) with the Statistical Analysis System (SAS, 1990). Rumen $\mathrm{pH}$ and $\mathrm{PR}$ data were analyzed separately using the general linear models procedure in SAS. Rumen $\mathrm{pH}$ and PR data were analyzed using a repeated measures design with animals as the main plot. Tukey's test was also performed on rumen $\mathrm{pH}$ data to measure adjustments for multiple comparisons within data. PR data were subjected to the general linear models procedure with animal, treatment and day as main effects. Day was analyzed as d 1 vs. $d 2$ to 5 to determine if $d 1$ variables were significantly different from the rest of the week. $\mathrm{PR}$ and $\mathrm{pH}$ were the dependent variables in this model. A Pearson correlation was conducted on $\mathrm{pH}$ vs. PR. All data were tested for normality prior to analysis. $\mathrm{P}<0.05$ was considered significant.

\section{RESULTS}

\section{Experiment 1 - SARA Model Development}

Average intake of TMR was $13.8 \mathrm{~kg} \mathrm{DM} \mathrm{d}^{-1}$ during SARA and $19.4 \mathrm{~kg} \mathrm{DM} \mathrm{d}^{-1}$ during Control. The average intake of WBP during SARA was $4.9 \mathrm{~kg} \mathrm{DM} \mathrm{d}^{-1}$. Two cows did not consume all of the WBP between 9 am and 10 am on all the days that SARA was induced. As a result, the remaining WBP, which never exceeded 1.5 $\mathrm{kg}$, was placed into the rumen through the cannula. Cows that received some WBP directly into the rumen did not have different rumen $\mathrm{pH}$ conditions than cows that ate the WBP. All cows consumed the WBP that were provided between $1 \mathrm{pm}$ and $2 \mathrm{pm}$. The continuous monitoring of rumen $\mathrm{pH}$ was used to determine the efficacy of SARA development in both experiments and allowed the calculations of time and area below $\mathrm{pH} 6.0$ and 5.6. In the SARA model development experiment (Expt. 1), average pH was $0.14 \pm 0.02$ units lower (6.11 vs. 6.25) in SARA weeks than in Control weeks (Table 2). Time $\mathrm{pH} 6(640.8 \pm 36.3 \mathrm{~min}$ vs. $318.5 \pm 36.3 \mathrm{~min})$ and Area $<\mathrm{pH} 6(157.3 \pm 13.7 \mathrm{~min} * \mathrm{pH}$ vs. $105.5 * 13.7$ 
KEUNEN ET AL.

Table 2. Summary of daily averages of continuous $\mathrm{pH}$ data for SARA model development (Expt. 1).

\begin{tabular}{llllll}
\hline Treatment & Avg. pH & $\begin{array}{l}\text { Time }<\mathrm{pH} \\
6.0\left(\mathrm{~min} \cdot \mathrm{d}^{-1}\right)\end{array}$ & $\begin{array}{l}\text { Area }<\mathrm{pH} 6.0 \\
\left(\min * \mathrm{pH} \cdot \mathrm{d}^{-1}\right)\end{array}$ & $\begin{array}{l}\text { Time }<\mathrm{pH} \\
5.6\left(\mathrm{~min}^{-1} \mathrm{~d}^{-1}\right)\end{array}$ & $\begin{array}{l}\text { Area }<\mathrm{pH} 5.6 \\
\left.\min * \mathrm{pH} \cdot \mathrm{d}^{-1}\right)\end{array}$ \\
\hline Control & $6.25^{\mathrm{a}}$ & $318.49^{\mathrm{a}}$ & $105.54^{\mathrm{y}}$ & 117.63 & 26.21 \\
SARA & $6.11^{\mathrm{b}}$ & $640.78^{\mathrm{b}}$ & $157.27^{\mathrm{z}}$ & 109.15 & 14.68 \\
SE & 0.02 & 36.31 & 13.66 & 16.19 & 4.97 \\
\hline
\end{tabular}

Data presented are LS means across treatments $\mathrm{N}=20$ traces.

${ }^{\mathrm{a}, \mathrm{b}}$ Different superscipts within column indicate $P<0.01$.

${ }^{\mathrm{y}, \mathrm{z}}$ Different superscripts within column indicate $P<0.05$.

a)

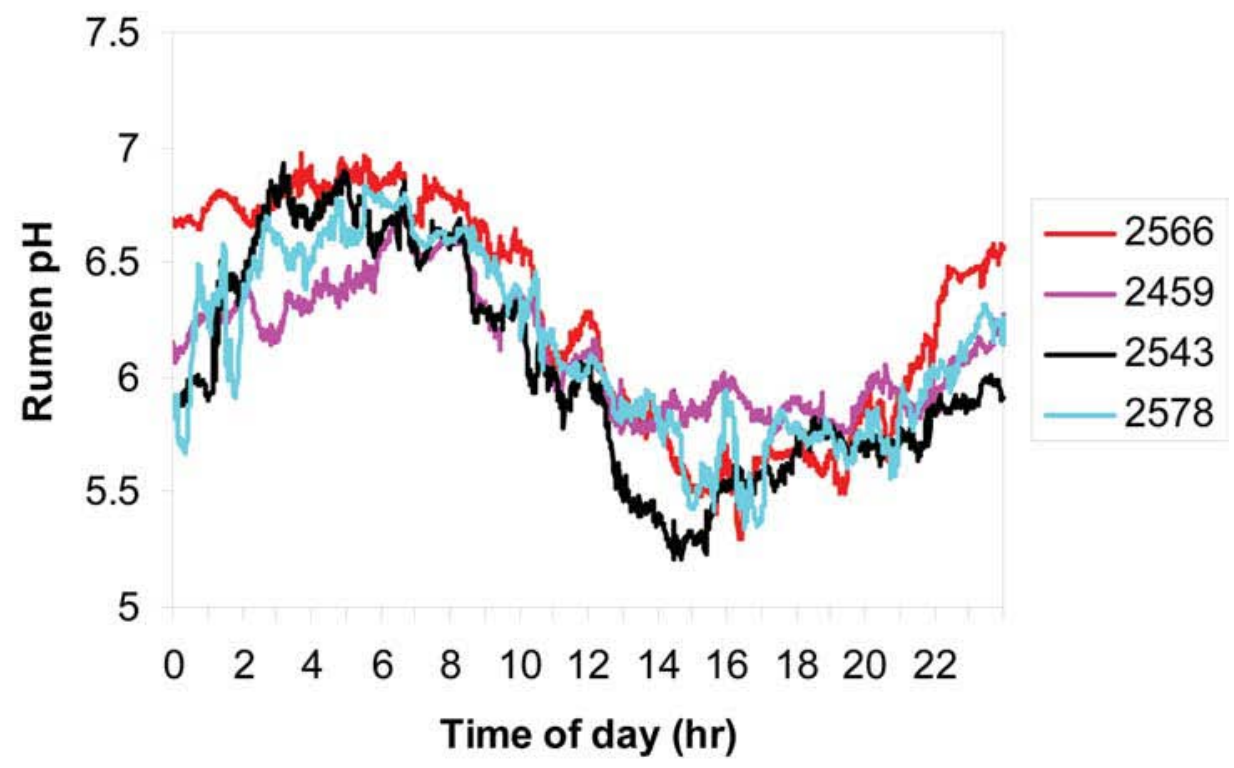

b)

7.5

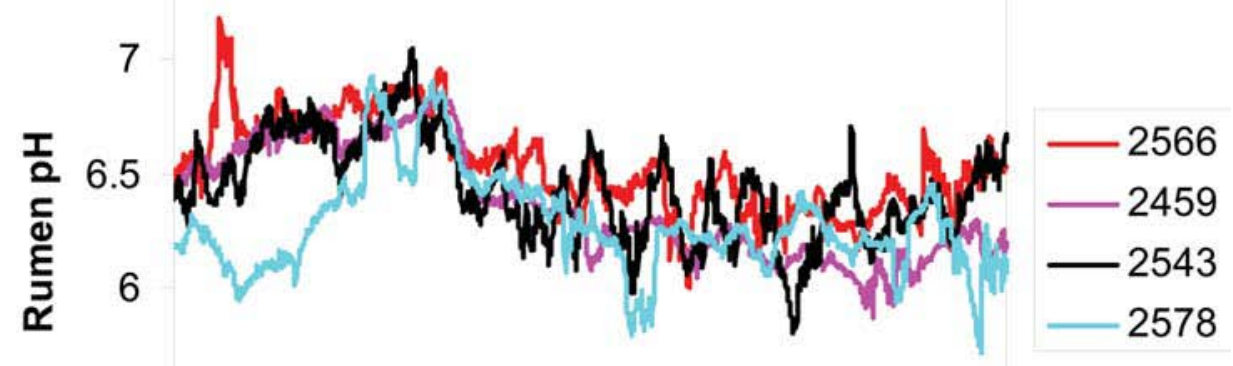

5.5

5

\section{$\begin{array}{llllllllllll}0 & 2 & 4 & 6 & 8 & 10 & 12 & 14 & 16 & 18 & 20 & 22\end{array}$ Time of day (hr)}

Figure 2. 24-hr. rumen $\mathrm{pH}$ trace of four cows subjected to a) Subacute Rumen Acidosis (SARA) feeding protocol or b) given access to ad libitum TMR. *Refer to Figure 1 for SARA feeding protocol. 
Table 3. Summary of daily averages of continuous pH data for Diet Choice (Expt. 2).

\begin{tabular}{|c|c|c|c|c|c|}
\hline & Avg. pH & $\begin{array}{l}\text { Time }<\mathrm{pH} \\
6.0(\mathrm{~min})\end{array}$ & $\begin{array}{l}\text { Area }<\mathrm{pH} \\
6.0(\min * \mathrm{pH})\end{array}$ & $\begin{array}{l}\text { Time }<\mathrm{pH} \\
5.6(\mathrm{~min})\end{array}$ & $\begin{array}{l}\text { Area }<\mathrm{pH} \\
5.6\left(\min ^{*} \mathrm{pH}\right)\end{array}$ \\
\hline SARA Days 2-5 & $5.93^{\mathrm{y}}$ & $830.79^{\mathrm{a}}$ & $263.00^{\mathrm{a}}$ & $263.53^{\mathrm{y}}$ & 10.08 \\
\hline Control Days 2-5 & $6.19^{\mathrm{z}}$ & $272.77^{\mathrm{b}}$ & $63.78^{\mathrm{b}}$ & $56.43^{\mathrm{z}}$ & 53.87 \\
\hline SARA Days $1-5$ & $5.98^{\mathrm{y}}$ & $806.55^{\mathrm{a}}$ & $263.93^{\mathrm{a}}$ & $261.82^{\mathrm{y}}$ & 48.98 \\
\hline Control Days 1-5 & $6.17^{\mathrm{z}}$ & $317.57^{\mathrm{b}}$ & $81.15^{\mathrm{b}}$ & $73.99^{\mathrm{z}}$ & 14.96 \\
\hline SARA Day 1 & 6.13 & 589.27 & 177.92 & 187.39 & 30.54 \\
\hline Control Day 1 & 6.09 & 496.75 & 150.63 & 144.25 & 34.47 \\
\hline $\mathrm{SE}$ & 0.03 & 22.77 & 21.02 & 30.81 & 13.75 \\
\hline
\end{tabular}

$\min * \mathrm{pH})$ were significantly greater in SARA weeks vs. Control weeks, respectively (Table 2). There were no significant differences between the two treatments when comparing Time $<\mathrm{pH} 5.6$ and Area $<\mathrm{pH} 5.6$ (Table 2).

A typical $\mathrm{pH}$ trace of the cows during SARA induction and a control trace can be seen in Figure 2. When TMR is first fed to the cows at $7 \mathrm{am}$, the $\mathrm{pH}$ ranges between 6.5-6.8. The $\mathrm{pH}$ slowly declines until the first WBP feeding at $9 \mathrm{am}$. At this point the $\mathrm{pH}$ declines further, dropping below $\mathrm{pH} 6.0$ at about 11 am. The 11 am TMR feeding along with the $1 \mathrm{pm}$ WBP feeding help to maintain depressed $\mathrm{pH}$. This model typically keeps the $\mathrm{pH}$ below 6.0 from 11 am until 8 to $9 \mathrm{pm}$. The rumen slowly returns to a normal rumen $\mathrm{pH}$ (6.3-6.8) overnight and is at its peak again the following morning. In our study rumen $\mathrm{pH}$ was the main variable in determining the efficacy of the SARA model. Average milk yield was $25.8 \mathrm{~kg} / \mathrm{d}$ during SARA and $26.6 \mathrm{~kg} / \mathrm{d}^{-1}$ during Control and was not significantly affected by treatment.

\section{Experiment 2 - Diet Choice}

Results from the Diet Choice experiment confirmed that the SARA model effectively reduced rumen $\mathrm{pH}$ to levels observed in the transition dairy cows used by Plaizier et al. (1999). Exclusion of Day 1 continuous $\mathrm{pH}$ data accentuated the underlying effect of diet on all measurable data except area $<\mathrm{pH} 5.6$. Rumen $\mathrm{pH}$ was significantly depressed by $0.26 \pm 0.03$ units (5.93 vs. 6.19) in SARA weeks compared to the Control week (Table 3). Time below pH 6.0 (845 \pm 23.9 min vs. 273 $\pm 23.9 \mathrm{~min})(\mathrm{P}<0.01)$, time below $\mathrm{pH} 5.6(280 \pm 42.8$ min vs. $56 \pm 42.8 \mathrm{~min})$, and area below $6.0(282 \pm 29.4$ $\min *$ pH vs. $64 \pm 29.4$ min $* \mathrm{pH})(\mathrm{P}<0.01)$ were significantly greater in SARA weeks compared to the Control week (Table 3). There was, however, no difference for area below pH $5.6(49 \pm 20 \mathrm{~min} * \mathrm{pH}$ vs. $10 \pm 20 \mathrm{~min}$ $* \mathrm{pH}$ ) between SARA and Control weeks (Table 3). Average $\mathrm{pH}$ for these days (6.13 for SARA and 6.09 for con- trol) rather indicate that the SARA model was not efficacious until d 2 of each SARA wk (Table 3).

Induction of the SARA model did not significantly affect milk yield and milk protein percentage (Table 4). However, induction of SARA significantly reduced milk protein percentage (Table 4).

DMI from TMR, WBP, alfalfa hay and alfalfa pellets are given in Table 5. This table shows that total DMI did not differ significantly between SARA and control periods. The two cows did not consume all of the WBP between 9 am and 10 am in the first experiment, also did not consume all of the WBP during their period in the second experiment. As a result, the remaining WBP, which never exceeded $1.5 \mathrm{~kg}$, was placed into the rumen of these two cows through the cannula. Cows that received some WBP directly into the rumen did not have different rumen $\mathrm{pH}$ conditions than cows that ate the WBP.

\section{Preference Ratios}

The PR for hay during each sampling day, as well as the average rumen $\mathrm{pH}$ of those cows during the diet choice period are presented in Figure 3. Average PR for hay were $0.85 \pm 0.03$ during the SARA weeks vs. $0.60 \pm 0.03$ during the control week $(\mathrm{P}<0.05)$. The PRs changed in relation to rumen $\mathrm{pH}$. On $\mathrm{d} 1$ of each of the 3 wk it was 0.47 (SARA wk l), 0.55 (Control), and 0.65 (SARA week 2), respectively. During d 2 of the SARA weeks, the average $\mathrm{pH}$ dropped (6.03 vs. 5.79), and the PR for hay by the cows increased to 0.91 and 0.83 (SARA

Table 4. Milk yield and milk composition for Experiment 2.

\begin{tabular}{lccc}
\hline Item & Control & SARA & SE \\
\hline Milk yield $\left(\mathrm{kg} \mathrm{d}^{-1}\right)$ & 23.9 & 22.6 & 1.40 \\
Milk fat $(\%)$ & 3.78 & 3.80 & 0.16 \\
Milk protein $(\%)$ & $3.66^{\mathrm{a}}$ & $3.55^{\mathrm{b}}$ & 0.02 \\
\hline
\end{tabular}

Note: ${ }^{\mathrm{a}, \mathrm{b}}$ - Different superscripts within a row indicate significant differences $(P<0.05)$. 
Table 5. Dry matter intake of various feeds and total DMI for experiment 2. SE within brackets.

\begin{tabular}{llllll}
\hline Item & $\begin{array}{l}\text { TMR } \\
\left(\mathrm{kg} \mathrm{DM} \mathrm{d}^{-1}\right)\end{array}$ & $\begin{array}{l}\text { WBP } \\
\left(\mathrm{kg} \mathrm{DM} \mathrm{d}^{-1}\right)\end{array}$ & $\begin{array}{l}\text { Alfalfa hay } \\
\left(\mathrm{kg} \mathrm{DM} \mathrm{d}^{-1}\right)\end{array}$ & $\begin{array}{l}\text { Alfalfa pellets } \\
\left(\mathrm{kg} \mathrm{DM} \mathrm{d}^{-1}\right)\end{array}$ & $\begin{array}{l}\text { Total DMI } \\
\left(\mathrm{kg} \mathrm{DM} \mathrm{d}^{-1}\right)\end{array}$ \\
\hline SARA Days 1-5 & $14.1(1.6)$ & $5.4(0.6)$ & $2.1(0.12)$ & $0.7(0.14)$ & $22.3(1.7)$ \\
Control Days 1-5 & $21.4(2.2)$ & 0 & $1.6(0.15)$ & $1.3(0.18)$ & $24.3(2.2)$ \\
\hline
\end{tabular}

Note: ${ }^{a, b}$ - Different superscripts within a row indicate significant differences $(\mathrm{p}<0.05)$.

week $1 \& 2$ ) from 0.47 and 0.65 , respectively $(\mathrm{P}<$ 0.001 )(Figure 3). On d 2 of the control week, rumen $\mathrm{pH}$ increased (6.4 vs. 6.0) and, subsequently, the PR for hay decreased from 0.55 to 0.50 (Figure 3). SARA was induced for both wk 2 and 4 . In wk 2 , the average $\mathrm{pH}$ for $\mathrm{d} 2$ to 5 was $5.61 \pm 0.04$, whereas in wk 4 the average $\mathrm{pH}$ for the same days was $5.88 \pm 0.04$. On days when rumen $\mathrm{pH}$ was low, cows' PR for hay was significantly increased in SARA wk 2 and 4 (Figure 3). A Pearson correlation of $\mathrm{pH}$ and $\mathrm{PR}$ revealed a negative correlation between the two variables of $-0.38(\mathrm{P}<0.001)$.

\section{DISCUSSION}

\section{SARA Model Development}

The main objective of the model development was to be able to reduce rumen $\mathrm{pH}$ below 6.0 and 5.6, whilst still maintaining intake. Several nutritional models attempting to induce SARA prior to the current model being presented were tried and determined to be unsuccessful by our lab. Feeds, such as high moisture corn (HMC), cracked dried corn grain (CG), and rolled barley, were all fed to the cows at various rates and feeding schedules in preliminary studies (data not shown). These feeds did not induce SARA, either due to an inability of the feeds to depress the rumen $\mathrm{pH}$ rapidly enough, or due to the cows' refusal to consume the feeds. WBP were chosen because of their rapid rumen degra-

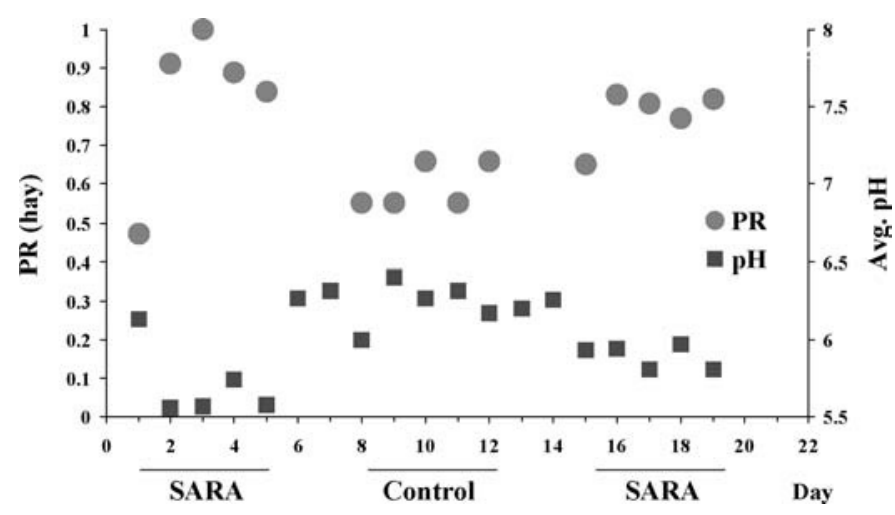

Figure 3. Average Preference Rations (PR) for Hay (0) by day and respective average rumen $\mathrm{pH}(\boldsymbol{\square})$ for all cows in Diet Selection experiment (Expt. 2). dability in comparison to the other feedstuffs, and because the pellets were readily consumed by the animals which resulted in a sustained drop in rumen $\mathrm{pH}$. The WBP proved to depress the rumen $\mathrm{pH}$ quickly and resulted in a sustained drop in rumen $\mathrm{pH}$.

\section{Rumen pH and Time Variables}

Chronic bouts of SARA are characterized by daily ruminal $\mathrm{pH}$ depressions between 5.2 and 5.6 (Cooper and Klopfenstein, 1996). Plaizier et al. (1999) have shown that transition dairy cows can spend more than $5 \mathrm{~h}$ with rumen $\mathrm{pH}$ being suppressed below 6.0 and upwards of $1 \mathrm{~h}$ with time below 5.6. It was important to develop a model with an extended period of time below both $\mathrm{pH} 6.0$ and 5.6, so that adequate time was provided to study the effects of SARA on intake preferences. Feeding two large meals of rapidly fermentable carbohydrates (wheat-barley pellets) was expected to act as the main factor in depressing ruminal $\mathrm{pH}$. The feeding schedule used was capable of sustaining rumen $\mathrm{pH}$ below 6.0 for a minimum of $8 \mathrm{~h}$. A grain supplementation of $25 \%$ of the diet on a dry matter basis as WBP pellets seemed to be the maximum rate of feeding in our model to reduce rumen $\mathrm{pH}$, without putting cows into acute acidotic conditions. Another study done by our lab group with a $30 \%$ grain supplementation led to rumen $\mathrm{pH}$ levels consistently below 5.0 (data not shown), and as a consequence the cows went off feed and displayed clinical symptoms of acidosis, such as loose feces, dull appearance, and weak rumen contractions (Underwood, 1992; Nocek, 1997). In contrast, in the present study we were successful in inducing SARA given that: i) cows were never off feed during the experimental periods; and ii) rumen $\mathrm{pH}$ increased overnight to normal rumen $\mathrm{pH}$ levels ( $\mathrm{pH}$ 6.3) prior to the morning feeding. Therefore, the feeding protocol could be and was repeated daily.

Results from Tables 2 and 4 show that the present model successfully decreased rumen $\mathrm{pH}$ in SARA weeks compared to control weeks. The significant increase $(\mathrm{P}<0.01)$ in time below $\mathrm{pH} 6.0>10.5 \mathrm{~h}$ for the SARA weeks compared to $5.3 \mathrm{~h}$ for the control weeks (Table 2 ), would have resulted in decreased digestibility or milk production often equated with subclinical acidosis 
(Calsamiglia et al., 1999; Stone, 1999; Cardozo et al., 2000).

Unique to our analytical approach was the quantification of area under $\mathrm{pH} 6.0$ and 5.6. This analysis not only showed the amount of time spent under the designated $\mathrm{pH}$, but also revealed the severity of the depression. Area under pH 6.0 was significantly greater in SARA weeks than in control weeks, indicating that the model increased time and area below $\mathrm{pH}$ 6.0, thus leading to alterations of fermentation and digestibility characteristics that were hoped to be sufficient in magnitude and duration to induce dietary selection of foodstuffs that would ameliorate SARA. The area below $\mathrm{pH} 5.6$ was not significantly different between SARA and control cows, showing that our $\mathrm{pH}$ depression below $\mathrm{pH}$ 5.6 did not reach levels where acute acidosis would have occurred.

It is believed that lactic acid was not the causal reason for $\mathrm{pH}$ reduction in this SARA model, as studies by Oetzel et al. (1999) and Plaizier et al. (1999) reported low lactate levels, i.e. between $0.45 \mathrm{mM}$ and $0.74 \mathrm{mM}$ in cows suspected of suffering from SARA.

\section{Diet Choice Experiment}

Time Variables. The dietary model caused rumen $\mathrm{pH}$ to be below 6.0 for more than $13 \mathrm{~h} \mathrm{~d}^{-1}$ during the two SARA weeks, compared to just over $4 \mathrm{~h} \mathrm{~d}^{-1}$ during the control week (Table 4 ). There was also a significant increase in time below $\mathrm{pH} 5.6$, as the model produced more than $4 \mathrm{~h}$ compared to the control weeks with less than $1 \mathrm{~h}$. Rumen $\mathrm{pH}$ depression below 5.6 for greater than $4 \mathrm{~h} / \mathrm{d}$ on average is a significant amount of time for a cow to experience SARA, and confirmed that this dietary model repeatably induced chronic bouts of SARA. The increased magnitude and deviation of SARA induced by WBP feeding between experiments can be attributed to several possibilities. One possibility is that the base diet composition changed between experiments, but comparison of the base TMR and WBP from both experiments revealed that the two diets were similar in both chemical and physical composition and ingredient proportion. Despite cows being later in lactation in experiment 2 compared with experiment 1 , DMI and WBP intakes were greater in the second experiment compared to the first experiment. It can be expected that these changes in DMI and WBP intake will have altered rumen conditions.

Preference Ratios. It appears that the full impact of the SARA model on rumen $\mathrm{pH}$ does not occur until d 2 of each week. This is likely a result of the SARA model's inability to reduce rumen $\mathrm{pH}$ on $\mathrm{d} 1$ of the SARA weeks. Due to the inability of the SARA model to reduce rumen $\mathrm{pH}$ on $\mathrm{d} 1$ of each week, the cows displayed random sampling of the two feed choices offered. As early as the next day, when rumen $\mathrm{pH}$ dropped in the SARA weeks, the cows clearly preferred the hay compared with the control week (Figure 3).

Previous work using sheep has related rumen acidosis to diet choice (Cooper et al., 1996; Phy and Provenza, 1998a; Phy and Provenza, 1998b). Acidosis was induced via direct addition of rapidly fermentable carbohydrates or organic acids to the rumen, and sheep manipulated diet selection and feed intake when offered feeds of different energy densities and infusing solutions directly into the rumen, to maintain optimal rumen conditions (Cooper et al., 1995). Phy and Provenza (1998a 1998b) have shown that sheep will choose a diet containing lasalocid or bicarbonate to attenuate acidosis. In the present study (Figure 3), cows distinctly chose hay after the initial $24 \mathrm{~h}$, perhaps because of the rumen $\mathrm{pH}$ depression causing a perceivable physiological shift that the cows recognized. This is similar to what Tolkamp et al. (1998) found with dairy cows when they made a shift in diet choice over a 48 -h period to select an appropriate level of rumen degradable protein. In fact, the scale of altered diet selection may not be of great importance, as the time needed for a change in diet selection to be observed is dependant on the deviation created in the animals state (Kyriazakis et al., 1999). Rather, as Kyriazakis et al. (1999) have suggested, the appropriate question in terms of diet selection is not "what time period matters to the animal?", but "how much change or deviation in the internal state is the animal prepared to accept?" The signal for increasing the dietary preference for alfalfa hay during SARA could have arisen from changes in the composition of the rumen contents or from changes in blood plasma variables. Data obtained in the present study do not allow the determination of which of these two mechanisms was responsible for the change in feeding behavior.

Provenza (1995) has suggested that previous learning and postingestive feedback play a role in diet selection. His learning model incorporated the animals' physiological state, neural interactions between senses (i.e. taste, smell), and viscera. Prior knowledge of the effects and postingestive consequences of feeds is certainly a possibility in our experiment. All cows in our trial were multiparous and had previously been offered hay and/ or pelleted feeds throughout their life. Also, during the transition period of lactation, when cows experience periods of SARA (Plaizier et al., 1999), all cows are fed hay daily and therefore they may have gained knowledge of its physical and chemical benefits prior to the existing trial.

The physical form of the alfalfa hay (long stem, high effective fiber), when compared with the alfalfa pellets 
(small particle size, low effective fiber), may also have had an impact on diet choice during SARA. Perhaps the cows preferred the long-stem hay to the alfalfa pellets to help fulfill, as Forbes (1995) describes it, a "craving" for roughage. This increased intake of roughage would lead to more time spent ruminating. Albright (1993) writes that considerable self-stimulation and "inwardness" occurs in cattle due to the rumination process and that during rumination, cows appear relaxed with their heads down and their eyelids lowered. As a consequence of cud-chewing and grooming, reduced aggression occurs in established groups and little or no boredom takes place in cattle (Albright, 1993). Stimulation of rumination could, therefore, improve overall cow well-being.

Several studies have found a link between increased fiber length or quantity of the diet and increased rumination time when forage has been varied by providing different levels of alfalfa pellets in the ration (Woodford and Murphy, 1988), by changing the lengths of grass silage fed (Castle et al., 1979), or by changing the ratio of high fiber pellets fed (Pulina et al., 1992). Woodford and Murphy (1988) have shown that replacing alfalfa haylage with alfalfa pellets significantly reduced time spent ruminating and total time spent chewing in lactating dairy cows. Castle et al. (1979) found similar results when they fed three different lengths of the same grass silage. It can be concluded that ruminants do not eat to achieve maximum efficiency, but rather to ensure proper rumen function (Forbes, 1995) such as rumination.

As suggested earlier, the cows' change in diet selection was likely brought about by physiological changes in rumen environment and/or content.. Consistent with this theory, Kryiazakis et al. (1999) suggested that animals modify their diet selection based on a sufficiently large physiological change in the animal's internal state. Although the mechanism that links diet selection and internal state is not well known or studied, a possible mechanism is discussed briefly below. Rumen acidosis and hypertonicity have been linked, as the production of VFA from microbial fermentation is one of the main determinants of the rise in osmolality in the rumen (Carter and Grovum, 1990). An increase in VFA will also lead to the depression of rumen $\mathrm{pH}$ and excessive acidity that reduces ruminal motility (Chrichlow, 1988). The link between intake, acidosis and osmolality leads to a possible answer of why SARA cows preferred alfalfa hay. We suggest that cows preferred a feed that did not lower the $\mathrm{pH}$ in the rumen and further inhibit digestion, motility, and feed intake in order to maintain rumination. Perhaps, the cows also looked to fulfill a "fiber appetite" (Campion and Leek, 1997) whereby ruminants alter diet selection to try to maintain rumen conditions within a certain physiological range (Parsons et al., 1994; Cooper and Klopfenstein, 1996).

It appears that cows consume feeds that initiate or maintain rumen-desired characteristics of composition and function. Whether there are neural and/or biochemical communications between cow comfort and rumination that provide an explanation of why the cows preferred alfalfa hay to alfalfa pellets remains to be determined. It may be that hay is a "comfort" food for dairy cows, and that when presented with any type of stressor, be it physiological (e.g. SARA) or behavioral (e.g. crowding), the cow may choose this feed over all others to increase overall well-being. Perhaps the induction of rumination from the consumption of the hay provides this feedback to the cow.

\section{CONCLUSIONS}

The experiments presented in this paper demonstrate that internal state (SARA) influences dietary choice in dairy cows. We were successful in creating a repeatable nutritional model that induces SARA to levels of those previously reported in transition dairy cows. We have also shown that when given a choice between alfalfa hay and alfalfa pellets, cows will choose the alfalfa hay more strongly when in a state of SARA. It is concluded that our SARA model created a sufficiently large change in the dairy cows' rumen environment to invoke a dietary change in selection. Thus we accepted the hypothesis that dairy cows would increase their dietary preference for a feed of longer particle size when given the appropriate choice during a bout of SARA.

\section{ACKNOWLEDGMENTS}

The authors wish to acknowledge the Dairy Farmers of Ontario, Ontario Ministry of Agriculture, Food and Rural Affairs, and the National Sciences and Engineering Research Council of Canada (NSERC) for their financial support without which this work could not be done. We would also like to thank Dr. Mark Froetschel for his helpful dialogue in preparation of this document. Thanks also go to the staff of the Elora Dairy Research Centre and our lab colleagues for their assistance during the experiments and analyses.

\section{REFERENCES}

Association of Official Analytical Chemists. 1990. Official Methods of Analysis. 15th ed. AOAC, Arlington, VA.

Albright, J. L., 1993. Feeding behavior of dairy cattle. J. Dairy Sci. 76:485-498.

Britton, R. A., and R. A. Stock. 1987. Pages 125-137 in Acidosis, rate of starch digestion and intake. Proc. 1986 Feed Intake Symp. Norman, OK. 
Calsamiglia, S., A. Ferret, J. Plaixats, and M. Devant. 1999. Effect of $\mathrm{pH}$ and $\mathrm{pH}$ fluctuations on microbial fermentation in a continuous culture system. J. Dairy Sci. 82(Suppl. 1):38.

Campion, D. P., and B. F. Leek. 1997. Investigation of a 'fibre appetite' in sheep fed a 'long fibre-free' diet. Appl. Anim. Behav. Sci. 52:79-86.

Cardozo, P. W., S. Calsamiglia, and A. Ferret. 2000. Effects of $\mathrm{pH}$ on microbial fermentation and nutrient flow in a dual flow continuous culture system. J. Dairy Sci. 83(Suppl. 1):265.

Carter, R. R. and W. L. Grovum. 1990. A review of the physiological significance of hypertonic body fluids on feed intake and ruminal function: salivation, motility and microbes. J. Anim. Sci. 68:2811-2832

Castle, M. E., W. C. Retter, and J. N. Watson. 1979. Silage and milk production: comparisons between grass silage of three different chop lengths. Grass and Forage Sci. 34:293-301.

Cooper, R., and T. Klopfenstein. 1996. Effect of Rumensin and Feed Intake Variation on Ruminal pH. Scientific Update on Rumensin/ Tylan/Micotil for the Professional Feedlot Consultant. Elanco Animal Health, Greenfield, IN.

Cooper, S. B. D., I. Kyriazakis, and J. D. Oldham. 1996. The effects of physical form of feed, carbohydrate source, and inclusion of sodium bicarbonate on the diet selections of sheep. J. Anim. Sci. $74: 1240-1251$

Cooper, S. B. D., I. Kyriazakis, and J. V. Nolan. 1995. Diet selection in sheep: the role of the rumen environment in the selection of a diet from two feeds that differ in their energy density. Br. J. Nutr. 74:39-54.

Dado, M. S., and R. A. Allen. 1993. Continuous computer acquisition of feed and water intakes, chewing, reticular motility, and ruminal $\mathrm{pH}$ of cattle. J. Dairy Sci. 76:1589-1600.

Duffield, T. F. 1999. Page 179 in A fistful of rumen-a novel approach to rumen fistula surgery. Bovine Proceedings No. 32. Proc. Am. Assoc. Bovine Pract.

Duffield, T. F., K. E. Leslie, D. Sandals, K. Lissemore, B. W. McBride, J. H. Lumsden, P. Dick, and R. Bag. 1999. Effect of a monensin controlled release capsule on cow health and reproductive performance. J. Dairy Sci. 82:2377-2384.

Forbes, J. M. 1995. Voluntary food intake and diet selection in farm animals. CAB International, Wallingford, U. K.

Garrett, E. F., M. N. Pereira, K. V. Norlund, L. E. Armentano, W. J. Goodger, and G. R. Oetzel. 1999. Diagnostic methods for the detection of subacute ruminal acidosis in dairy cows. J. Dairy Sci. 82:1170-1 178 .

Goering, H. K., and P. J. Van Soest. 1970. Forage fiber analysis (apparatus, reagents, procedures, and some application). Agric. Handbook No. 379, ARS-USDA, Washington, D.C.

Kyriazakis, I., B. J. Tolkamp and G. Emmans. 1999. Diet selection and animal state: an integrative framework. Proc. Nutr. Soc. $58: 765-772$.
Nocek, J. E. 1997. Bovine acidosis: implications on laminitis. J. Dairy Sci. 80:1005-1028.

Oetzel, G. R., K. V. Norlund, and E. F. Garrett. 1999. Effect of ruminal $\mathrm{pH}$ and stage of lactation on ruminal lactate concentrations in dairy cows. J. Dairy Sci. 82(Suppl. 1):38 (Abstr.).

Owens, F. N., and A. L. Goetsch. 1988. Ruminal fermentation. Pages 145-171 in The Ruminant Animal. Digestive Physiology and Nutrition. D. C. Church, ed.

Owens, F. N., D. S. Secrist, W. J. Hill, D. R. Gill. 1998. Acidosis in cattle: a review. J. Anim. Sci. 76:275-286.

Parsons, A. J., J. A. Newman, P. D. Penning, A. Harvey, and R. J. OK. 1994. Diet preference in sheep: effects of recent diet, physiological state and species abundance. J. Anim. Ecol. 63:465-478.

Phy, T. S. and F. D. Provenza. 1998a. Sheep fed grain prefer foods and solutions that attenuate acidosis. J. Anim. Sci. 76:954-960.

Phy, T. S. and F. D. Provenza. 1998b. Eating barley too frequently or in excess decreases lambs' preference for barley but sodium bicarbonate and lasalocid attenuate the response. J. Anim. Sci. 76:1578-1583.

Plaizier, J. C., A. Martin, T. Duffield, R. Bagg, P. Dick, and B. W. McBride. 1999. Monitoring acidosis in the transition dairy cow. J. Dairy Sci. 82:(Suppl. 1):110 (Abstr.).

Plaizier, J. C., J. E. Keunen, J-P. Walton, T. F. Duffield, and B. W. McBride. 2001. Effect of subacute ruminal acidosis on in-situ digestion of mixed hay in lactating dairy cows. Can. J. Anim. Sci. 81:421-423.

Provenza, F. D. 1995. Postingestive feedback as an elementary determinant of food preference and intake in ruminants. J. Range Management 48:2-17.

Pulina, G., G. Rossi, A. Cannas, P. Brandano, S. P. G. Rassu, and A. Serra. 1992. Page 376 in The use of a pelleted feed as stimulator of chewing activity in dairy sheep. Proc. 43rd Ann. Mtg. Euro. Assoc. Animal Prod. Madrid. SAS. 1990.

SAS User's Guide: Statistics. SAS Institute, Cary, NC.

Stone, W. C. 1999. The effect of subclinical rumen acidosis on milk components. Pages 40-46 in Proc. Cornell Nutr. Conf.

Tolkamp, B. J., I. Kyriazakis, J. D. Oldham, M. Lewis, R. J. Dewhurst, and J. R. Newbold. 1998. Diet choice by dairy cows. 2. Selection for metabolizable protein or for ruminally degradable protein? J. Dairy Sci. 81:2670-2680.

Undersander, D., D. R. Mertens, and N. Theix. 1993. Forage Analyses Procedures. National Forage Testing Association. Omaha, NE.

Underwood, W. J. 1992. Rumen lactic acidosis. Part I. Epidemiology and pathophysiology. Compend. Contin. Edu. Pract. Vet. 14: 1127-1133.

Woodford, S. T. and M. R. Murphy. 1988. Effect of forage physical form on chewing activity, dry matter intake, and rumen function of dairy cows in early lactation. J. Dairy Sci. 74:674-686. 